\title{
Evaluation of Total Hydrocarbons Levels and Traces Metals in Water and Sediment from Main Outfall Drain in Al-Nassiriya City/Southern Iraq
}

\author{
Afrah A. Maktoof ${ }^{1}$, Basim Y. ALKhafaji ${ }^{1}$, Zahraa Z. Al-janabi2 ${ }^{*}$ \\ ${ }^{1}$ Department of Biology, Collage of Science, Thi-Qar University, Nassiriya, Iraq \\ ${ }^{2}$ Environmental Research Center, University of Technology, Baghdad, Iraq \\ Email: zahraa zahraw@yahoo.com
}

Received 17 July 2014; revised 20 August 2014; accepted 3 September 2014

Copyright (C) 2014 by authors and Scientific Research Publishing Inc.

This work is licensed under the Creative Commons Attribution International License (CC BY).

http://creativecommons.org/licenses/by/4.0/

(c) (i) Open Access

\begin{abstract}
This study was conducted during Dec2011-Nov2012 on three stations located in the south sector of Main Outfall Drain (MOD) River. Station 1 was near Al-Holandee Bridge which was the general carriage way in the center of Al-Nassiriya city, station 2 was $20 \mathrm{~km}$ far from the first station, while station 3 was in the beginning of the new branch. This study reveals the Seasonal Variation of Total petroleum hydrocarbons (TPHs) in both surface waters, sediment and it is related with trace metals nickel and vanadium in water (dissolved, particulate) and sediment (residual and exchangeable) phases. Also, the study shows the relationships between the concentration of $\mathrm{Ni}$ and $\mathrm{V}$ with Total Organic Carbon (TOC\%) in the sediment.
\end{abstract}

\section{Keywords}

Total Petroleum Hydrocarbons, Traces Metals, Water, Sediment, Main Outfall Drain

\section{Introduction}

The extraction and usage of petroleum products as energy sources around the world have led to a wide spread of pollution in the biosphere. About 6 - 10 million barrels of crude oil enter the aquatic environment yearly [1]. The control of such pollution problems in the aquatic environment is very difficult because of the large number of input sources and their geographic dispersions. Contrary to popular views, evidence is accumulating to buttress

"Corresponding author.

How to cite this paper: Maktoof, A.A., ALKhafaji, B.Y. and Al-janabi, Z.Z. (2014) Evaluation of Total Hydrocarbons Levels and Traces Metals in Water and Sediment from Main Outfall Drain in Al-Nassiriya City/Southern Iraq. Natural Resources, 5, 795-803. http://dx.doi.org/10.4236/nr.2014.513068 
the fact that petroleum hydrocarbons mix with water and penetrate to the sediment [2]-[4].

Hydrocarbons in the aquatic environment have several sources which can be classified either as anthropogenic or as biogenic. Major sources of total petroleum hydrocarbons (TPHs) enter into water by many routes of various activities such as oil refineries, off shore oil production, transportation and tanker accident [5]. Moreover, river runoff, urban runoff, municipal wastes and inland wastes are also found significant inputs of petroleum hydrocarbons and its derivatives entering the environment.

In Iraq, numerous studies were done to determine the total hydrocarbon pollutants in the aquatic ecosystem and limited to southern of Iraqi water where many activities of oil production, refining and transportation took place [6]-[8].

There is no any previous studies about the TPHs in Main Outfall Drain (MOD) near Al-Nissiryia city, so the aim of this study is to provide information on the level of TPHs of the surface waters, sediment and its related metals, nickel and vanadium in water (dissolved, particulate) and sediment (residual and exchangeable) phases by studying their seasonally variation and correlations. Also relationships between the concentration of $\mathrm{Ni}$ and $\mathrm{V}$ with Total Organic Carbon (TOC\%) in the sediment are studied.

\section{Materials and Methods}

\subsection{Study Area}

Samples are taken monthly from Main Outfall Drain (MOD) which is a river used to discharge the effluents of agriculture activities from its both sides. It is extended from Al-Shaklawiya (near north of Baghdad) to Al-Basrah (at the south of Iraq) with length about $565 \mathrm{~km}$ [9]. It is divided into three sectors (North, Mid and South), the south sector (where the present study is a part of its) extended from the end of the mid sector to Shatt Al-Basarah, with length about $165 \mathrm{~km}$. The discharge of water is $220 \mathrm{~m}^{3} / \mathrm{sec}$ in this sector [10]. New branch is opened in this sector with length $7 \mathrm{~km}$ that is used to transform water to marshes in south of Al-Nassiriya city.

Three stations were selected in the south sector of this River to implement the present study. Station 1 (St.1) was located near Al-Holandee bridge and it's the general carriage way in the center of Al-Nassiriya city, St.2 was $20 \mathrm{~km}$ far from the first station, while St.3 was located the beginning of the new branch (Figure 1).

\subsection{Laboratory Work}

The Total Organic Carbon (TOC\%) concentration in sediment samples was determined according to the method of Gaudette et al. (1974) [12]. The organic carbon content was determined by back titration of excess potassium dichromate with ammonium ferrous sulphate using diphenylamine as indicator. For determined Total petroleum hydrocarbons (TPHs) three surface water samples were collected using Nisken bottles. In addition, three surface sediment samples were collected using van veen Grab Sampler from the study area (Figure 1).

Sediment and water samples collected in the field were delivered to the laboratory for mechanical and petroleum hydrocarbons analysis, while the samples for TPHs were measured by using the UVF spectrofluorometer (Sequoio-Turner Model 450), according to Parsons et al. (1984) [13].

For determination of dissolved hydrocarbons in water samples one litter of water was poured in to $2 \mathrm{~L}$ capacity glass separating funnels, extracted twice with $40 \mathrm{ml}$ of methylene chloride and evaporated to dryness at $30^{\circ} \mathrm{C}$, using the rotary evaporated under reduced pressure. The concentrate was dissolved in $10 \mathrm{ml} \mathrm{n}$-Hexane and measured fluorometrically at $415 \mathrm{~nm}$ after excilation at $360 \mathrm{~nm}$. Chrysene was used for the standard calibration graph n-Hexane as diluents. The reduce extract was carefully pipetted into a precleaned $10 \mathrm{ml}$ volumetric flask, making sure any residual particulate of sodium sulphate were excluded and evaporated to dryness by a stream of pure nitrogen. Final extracts in hexane were concentrated to $5 \mathrm{ml}$. Before extracting suspended particulate matter, the particulate fractions on glass fiber filter were freeze dried in Edward K4 Freeze-dryer Modulyo.

The extraction of suspended particulate matter procedure was based upon Goutx and Saliot (1980) [14]. Before analysis, sediment samples were freeze-dried, ground finally in a gate mortar and sieved through a $62 \mu \mathrm{m}$ metal sieve (stainless steel).

The extraction of TPHs residues in sediment sample is based upon that of Howell (1961) [15], the extraction is based on the formation of complex determined calorimetrically as a phosphotagsto vanodic acid [16].

Determination of Ni and V in water samples (dissolved phases) were carried out using the method [15]. Suspended particulate matter was extracted according to procedure of [17] for exchangeable fraction of sediments 


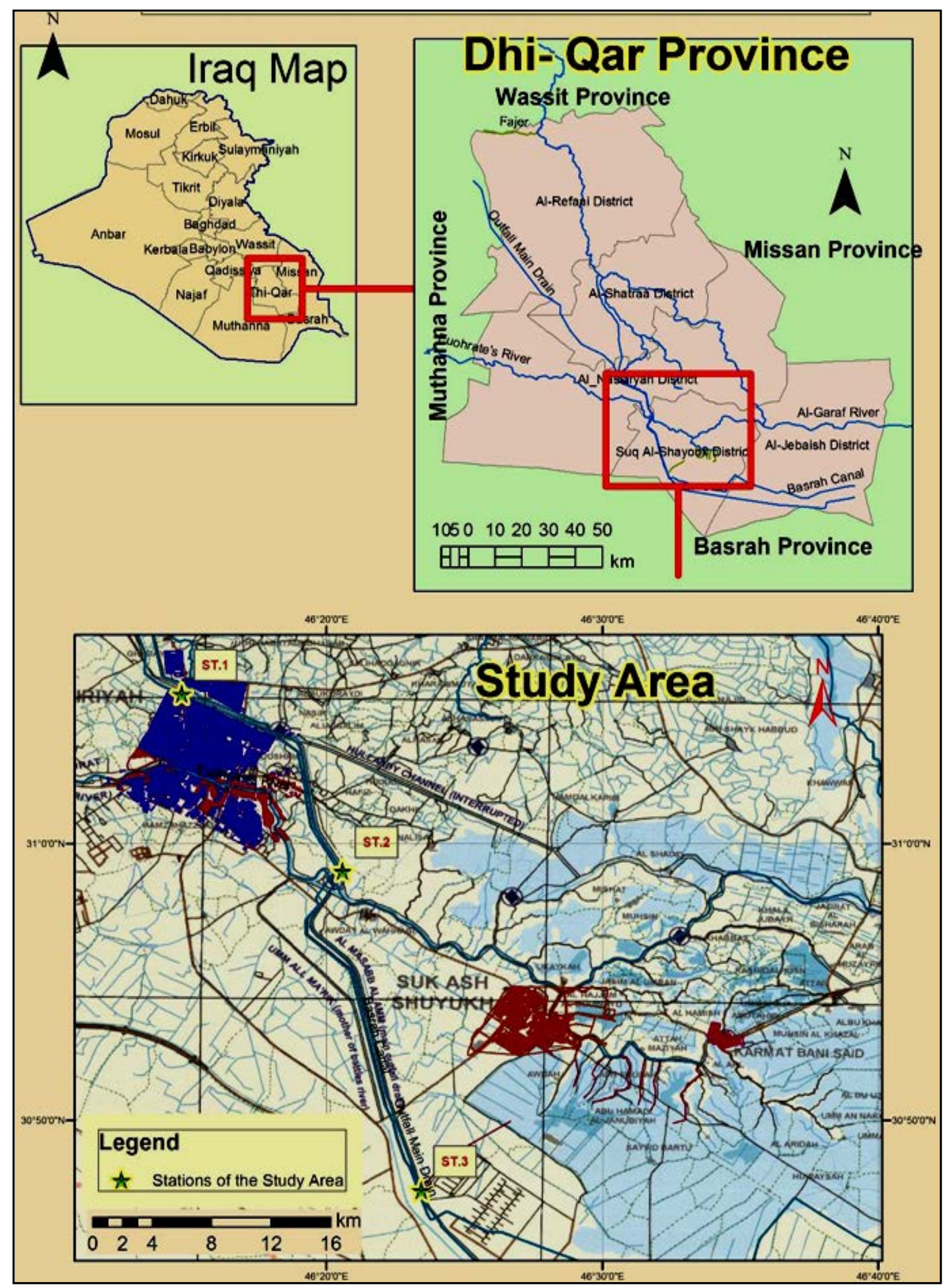

Figure 1. Map showed the study stations on main outfall drain in Al-Nassiriya city/southern of Iraq [11]. 
extraction was carried out using the method of [18], while the residual was extracted according to [17]. The determination of the vanadium element was carried out an LKB (biochrom) Uiltraspec II 4050 UV/VIS spectrophotometer.

\section{Results}

Mean seasonally concentrations of TPHs residues in water sample of "dissolved phase" from the selected three stations were recorded and listed in Table 1. In general the concentration of TPHs residues in "dissolved phase" were much higher during winter seasons than those recorded during summer season.

Table 2 showed the annual average values of TPHs in the water (dissolved phase), where station 1 revealed a higher concentration $5.3(\mu \mathrm{g} / \mathrm{l})$ through the year.

The average values of (TPHs) in "particulate" hydrocarbons varied from (0.021) to (6.67) ( $\mu \mathrm{g} / \mathrm{g})$ in station 3 and 1 respectively during summer, and from 0.31 in station 3 to $15.84(\mu \mathrm{g} / \mathrm{g})$ in station 1 during winter. Concentrations substantially higher during winter, while at summer they were drastically lower (Table 3). The annual concentrations of (TPHs) in the particulate phase of water also were higher in station 1 (Table 4).

\begin{tabular}{|c|c|c|c|c|}
\hline \multirow{2}{*}{ Station number } & \multicolumn{4}{|c|}{ Average concentration $(\mu \mathrm{g} / \mathrm{l})$} \\
\hline & Winter & Spring & Summer & Autumn \\
\hline 1 & 8.76 & 4.80 & 3.08 & 4.56 \\
\hline 2 & 6.55 & 3.86 & 2.13 & 3.32 \\
\hline 3 & 0.076 & 0.028 & 0.008 & 0.022 \\
\hline
\end{tabular}

Table 2. Annual average values of TPHs in the water (dissolved phase) ( $\mu \mathrm{g} / \mathrm{l})$ MOD during the study period.

\begin{tabular}{cc}
\hline Station number & Average concentration $(\mu \mathrm{g} / \mathrm{l})$ \\
\hline 1 & 5.3 \\
2 & 3.96 \\
3 & 0.028 \\
\hline
\end{tabular}

Table 3. Seasonal concentration values $(\mu \mathrm{g} / \mathrm{g}$ ) dry weight of TPHs in the particulate matter from MOD.

\begin{tabular}{ccccc}
\hline \multirow{2}{*}{ Station number } & \multicolumn{4}{c}{ Average concentrations $(\mu \mathrm{g} / \mathrm{g})$ dry weight } \\
\cline { 2 - 5 } & Winter & Spring & Summer & Autumn \\
\hline 1 & 15.84 & 12.44 & 6.67 & 10.83 \\
2 & 12.86 & 9.95 & 6.20 & 8.60 \\
3 & 0.31 & 0.12 & 0.021 & 0.15 \\
\hline
\end{tabular}

Table 4. Annual concentrations of (TPHs) in the particulate phase of water from MOD.

\begin{tabular}{cc}
\hline Station number & Average concentration $(\mu \mathrm{g} / \mathrm{g})$ dry weight \\
\hline 1 & 11.44 \\
2 & 9.40 \\
3 & 0.15 \\
\hline
\end{tabular}


The Average Seasonal concentrations of TPHs in bottom sediments reveled that station 1 has the higher concentrations in all season in comparable to other stations (Table 5). Table 6 which represents the Annual of TPHs in bottom sediments shows that station 1 has the higher value comparable to other stations.

In general, the concentration of TPHs in the dissolved phase was lower than that in particulate matter and sediments. Higher concentrations were observed in station 1, while the lowest concentration was in station 3.

The TOC\% in the sediment were determined for the same periods of study, they are listed in Table 7, where station 1 also revealed the higher concentrations in all season comparable to other stations.

Seasonal variations in values of dissolved V were observed in all stations, the highest of $75.53 \mu \mathrm{g} / \mathrm{l}$ in station 1 during winter, whereas lowest values was undetectable in station 3 at summer (Table 8). Seasonal variation in particulate matter showed that highest mean concentration value of $\mathrm{V}$ in station 1 was $200.67 \mu \mathrm{g} / \mathrm{g}$ at summer, whereas the lowest value was not detectable in station 3 during spring (Table 8).

The mean concentration of exchangeable and residual in sediment were recorded and listed in Table 9, where the concentrations of both exchangeable and residual are high in summer in all stations.

Table 10 showed the mean concentration of $\mathrm{Ni}$ in the water, where the highest concentration of dissolved $\mathrm{Ni}$ in water was $82.99(\mu \mathrm{g} / \mathrm{l})$ in station 1 during winter and the highest concentration in particulate matter was $298.33(\mu \mathrm{g} / \mathrm{g})$ dry weight in station 1 during summer.

The mean concentration of $\mathrm{Ni}$ in sediment from the same stations are listed in Table 11, where the highest concentration of $\mathrm{Ni}$ in the exchangeable phase was $70.12(\mu \mathrm{g} / \mathrm{g})$ in station 2 during summer while in residual phases was $101.08(\mu \mathrm{g} / \mathrm{g})$ in station 1 during the same season.

\begin{tabular}{|c|c|c|c|c|}
\hline \multirow{2}{*}{ Station number } & \multicolumn{4}{|c|}{ Average concentrations ( $\mu \mathrm{g} / \mathrm{g}$ ) dry weight } \\
\hline & Winter & Spring & Summer & Autumn \\
\hline 1 & 5.70 & 4.30 & 2.81 & 4.20 \\
\hline 2 & 4.40 & 3.20 & 1.60 & 2.8 \\
\hline 3 & 0.44 & 0.18 & 0.09 & 0.20 \\
\hline
\end{tabular}

Table 6. Annual average values of TPHs in the sediment $(\mu \mathrm{g} / \mathrm{g})$ in dry weight from MOD.

\begin{tabular}{cc}
\hline Station number & Average concentration $(\mu \mathrm{g} / \mathrm{g})$ dry weight \\
\hline 1 & 4.25 \\
2 & 3.75 \\
3 & 0.23 \\
\hline
\end{tabular}

Table 7. Seasonal variations of TOC\% content and (Mean \pm SD) in dry weight sediment.

\begin{tabular}{ccccc}
\hline \multirow{2}{*}{ Station number } & \multicolumn{4}{c}{ Average concentrations $(\mu \mathrm{g} / \mathrm{g})$ dry weight } \\
\cline { 2 - 5 } & Winter & Spring & Summer & Autumn \\
\hline 1 & 1.04 & 0.84 & 1.54 & 1.05 \\
3 & 0.55 & 0.41 & 0.74 & 0.55 \\
Mean & 0.25 & 0.20 & 0.33 & 0.25 \\
\pm SD & 0.61 & 0.48 & 0.87 & 0.61 \\
& 0.1 & 0.07 & 0.18 & 0.11 \\
\hline
\end{tabular}


Table 8. Mean concentration, $\pm \mathrm{SD}$ of $\mathrm{V}$ of dissolved water $(\mu \mathrm{g} / \mathrm{l})$ and particulate matter $(\mu \mathrm{g} / \mathrm{g})$ dry weight from MOD in different season.

\begin{tabular}{|c|c|c|c|c|c|c|}
\hline \multirow{3}{*}{ Seasons } & \multicolumn{6}{|c|}{ Water } \\
\hline & \multicolumn{2}{|c|}{ Station 1} & \multicolumn{2}{|c|}{ Station 2} & \multicolumn{2}{|c|}{ Station 3} \\
\hline & Diss. \pm SD & Part. \pm SD & Diss. \pm SD & Part. \pm SD & Diss. \pm SD & Part. \pm SD \\
\hline Winter & $75.53 \pm 3.06$ & $171.86 \pm 96.98$ & $30.22 \pm 0.16$ & $100.67 \pm 60.08$ & $2.99 \pm 0.15$ & $32.04 \pm 0.18$ \\
\hline Spring & $39.77 \pm 2.95$ & $198.55 \pm 167.09$ & $25.37 \pm 0.56$ & $105.55 \pm 42.06$ & $1.75 \pm 0.09$ & N.D \\
\hline Summer & $41.89 \pm 1.66$ & $200.67 \pm 98.07$ & $15.71 \pm 1.97$ & $102.8 \pm 56.02$ & N.D & $40.32 \pm 2.06$ \\
\hline Autumn & $42.65 \pm 1.05$ & $68.96 \pm 50.01$ & $9.46 \pm 1.43$ & $70.67 \pm 20.03$ & $1.97 \pm 0.12$ & $29.5 \pm 8.86$ \\
\hline
\end{tabular}

Table 9. Mean concentration $(\mu \mathrm{g} / \mathrm{g})$ dry weight, \pm SD of Vanadium in the Exchangeable and Residual phases of the sediment in the study area.

\begin{tabular}{|c|c|c|c|c|c|c|}
\hline \multirow{3}{*}{ Seasons } & \multicolumn{6}{|c|}{ Sediment } \\
\hline & \multicolumn{2}{|c|}{ Station 1} & \multicolumn{2}{|c|}{ Station 2} & \multicolumn{2}{|c|}{ Station 3} \\
\hline & Ex. \pm SD & Res. \pm SD & Ex. \pm SD & Res. \pm SD & Ex. \pm SD & Res. \pm SD \\
\hline Winter & $20.25 \pm 2.21$ & $16.16 \pm 2.00$ & $17.37 \pm 2.94$ & $21.25 \pm 9.59$ & $3.58 \pm 0.73$ & $2.01 \pm 0.71$ \\
\hline Spring & $15.08 \pm 0.75$ & $13.42 \pm 1.12$ & $14.17 \pm 2.20$ & $16.5 \pm 8.86$ & $3.00 \pm 0.54$ & $2.98 \pm 0.41$ \\
\hline Summer & $22.83 \pm 3.51$ & $23.75 \pm 5.16$ & $24.67 \pm 3.50$ & $25.75 \pm 64.02$ & $5.23 \pm 1.27$ & $4.42 \pm 0.98$ \\
\hline Autumn & $10.21 \pm 0.60$ & $12.46 \pm 1.28$ & $13.33 \pm 2.93$ & $14.99 \pm 3.33$ & $2.56 \pm 0.44$ & $2.22 \pm 0.40$ \\
\hline
\end{tabular}

Table 10. Mean concentration, \pm SD of Ni of dissolved water $(\mu \mathrm{g} / \mathrm{l})$ and particulate matter $(\mu \mathrm{g} / \mathrm{g})$ dry weight from MOD in different season.

\begin{tabular}{|c|c|c|c|c|c|c|}
\hline \multirow{3}{*}{ Seasons } & \multicolumn{6}{|c|}{ Water } \\
\hline & \multicolumn{2}{|c|}{ Station 1} & \multicolumn{2}{|c|}{ Station 2} & \multicolumn{2}{|c|}{ Station 3} \\
\hline & Diss. \pm SD & Part. \pm SD & Diss. \pm SD & Part. \pm SD & Diss. \pm SD & Part. \pm SD \\
\hline Winter & $82.99 \pm 6.23$ & $199 \pm 11.8$ & $29.23 \pm 1.06$ & $106.00 \pm 82.72$ & $2.99 \pm 0.24$ & $30 \pm 5.0$ \\
\hline Spring & $35.00 \pm 2.28$ & $160 \pm 82.72$ & $26.02 \pm 0.57$ & $120.67 \pm 35.46$ & $1.75 \pm 0.08$ & N.D \\
\hline Summer & $41.6 \pm 2.31$ & $298.33 \pm 91.58$ & $18.36 \pm 0.20$ & $130.33 \pm 90.04$ & $0.51 \pm 0.24$ & $22.67 \pm 8.06$ \\
\hline Autumn & $35.00 \pm 1.05$ & $102.83 \pm 38.39$ & $9.46 \pm 0.06$ & $82.46 \pm 50.01$ & $2.00 \pm 0.57$ & $30.5 \pm 7.66$ \\
\hline
\end{tabular}

Table 11. Mean concentration ( $\mu \mathrm{g} / \mathrm{g})$ dry weight, $\pm \mathrm{SD}$ of Ni in the exchangeable and residual phases of the sediment in the study area.

\begin{tabular}{|c|c|c|c|c|c|c|}
\hline \multirow{3}{*}{ Seasons } & \multicolumn{6}{|c|}{ Sediment } \\
\hline & \multicolumn{2}{|c|}{ Station 1} & \multicolumn{2}{|c|}{ Station 2} & \multicolumn{2}{|c|}{ Station 3} \\
\hline & Ex. \pm SD & Res. \pm SD & Ex. \pm SD & Res. \pm SD & Ex. \pm SD & Res. \pm SD \\
\hline Winter & $35.75 \pm 2.21$ & $52.42 \pm 5.17$ & $30.29 \pm 2.38$ & $28.75 \pm 5.16$ & $12.42 \pm 2.21$ & $10.75 \pm 2.21$ \\
\hline Spring & $29.42 \pm 1.50$ & $40.67 \pm 40.02$ & $22.42 \pm 0.72$ & $20.25 \pm 2.26$ & $8.25 \pm 1.01$ & $6.42 \pm 1.51$ \\
\hline Summer & $40.83 \pm 5.16$ & $101.08 \pm 9.52$ & $70.12 \pm 28.8$ & $75.67 \pm 11.12$ & $21.15 \pm 5.16$ & $18.92 \pm 5.02$ \\
\hline Autumn & $25.17 \pm 1.03$ & $30.29 \pm 2.39$ & $9.92 \pm 2.21$ & $15.08 \pm 1.28$ & $11.79 \pm 1.28$ & $12.37 \pm 0.31$ \\
\hline
\end{tabular}




\section{Discussion}

River that flow through agriculture and urban industrial area carry a great number and variety of pollutants, therefore the examination of different properties in quit essential [19].

Water pollution by TPHs may be associated with the anthropogenic activities that represented the major source of TPHs in addition to natural source [20]-[22].

The rate elevated concentrations recorded for station 1 may be due to proximity to the city of Al-Nassiriya city which receives sewage discharge, sludge dumping and industrial effluents. It is reported that St.1 is affected by domestic waste, human waste discharge as well as fishing boats [23].

There is a direct relationship between TPHs (in dissolved phase) and Nickel and Vanadium (in dissolved phase) where correlation coefficient were $(r=0.59)$ and $(r=0.50)$ for TPHs with Ni and V respectively.

Particulate matters in water are essential composed for both living organisms and recent biological materials. This latter part, which rapidly settles, carries other contributions due to interactions with other pools and dissolved water and small size particles. An increase in the concentration of particulate hydrocarbons could result from primary production and/or increase in the concentration of suspended matter.

Seasonal variations in the concentrations of TPHs in the water from MOD were very clear in which higher levels were reported during winter, while lower were reported during summer, this variation is the nature of climate in the area which characterized by two extreme seasons with high differences in temperature winter and summer. These reasons lead to different effects of microbial degradation [24], photo-oxidation [25].

In general, the concentration of TPHs in water depend on several factors including properties of TPHs as hydrophobic nature with low solubility [26] [27], interaction of several processes such as volatilization, bio concentration, sedimentation solubilization and biodegradation [8] [21] [28].

The weak positive correlation between TPHs in particulate matter and $\mathrm{Ni}$ and $\mathrm{V}$ "in particulate matter" where correlation coefficient for $\mathrm{Ni}$ was $(r=0.100)$ and $\mathrm{V}$ was $(r=0.140)$ in station 1 , 2, while there is a negative in station 3 because it is far from contamination source. Concentration values listed in Table 5, for TPHs in the sediment from MOD, revealed that TPHs in the sediments have the same trend as those water in which higher level were recorded in rainy season than in the dry season, and during all seasons the lower values were recorded in St.3 and higher values were recorded in St.1. The oil must have washed into the river from land based sources during the rainy season, in these station, besides increased water current and wave action, which may Longley disturb the sediment with the concomitant resurfacing of previously leached hydrocarbon in to the sediment [29]. It has been remarked that high temperature and high rates of microbial activities are known to cause rapid degradation petroleum hydrocarbons released in to environment [30].

The seasonal variation of temperature affected the degradation rate of petroleum hydrocarbons present in the surface layer moreover the fast degradation taking place in the surface layer catching the water bottom which characterized with oxygen abundant [31]. In addition to that deposition of petroleum hydrocarbons towards, the bottom lead to increase the bacterial aggregates which feed upon them, then the biodegradation will increase in the area following the increase oxygen and nutrients like phosphate and nitrate [32]. This is why petroleum hydrocarbons are high at winter and low at summer [33].

As usual levels of TPHs in sediment are much higher than those dissolved in the water column. Sediments are the final place for degradable as well as non degradable organic matter pollutant. TOC\% plays an important role in the accumulation and release of different micro pollutants. In addition to that TOC\% content can be considered as an indicator of hydrocarbons pollution only when the TOC\% is very high [34], high concentration of TOC\% was recorded in sediments from station 1 due to sewage discharge from Al-Nassiriya city, sludge dumping and industrial effluents.

There is a weak relationship between TPHs (in sediment) and Nickel (in exchangeable phase) in station 1 ( $\mathrm{r}=$ 0.154 ), while there is positive correlation between TPHs (in sediment) and Vanadium (in exchangeable phase) in station 1, $2(r=0.62)$, whereas station 3 shows that are negative correlation. The results in this study revealed the presence of positive significant correlation between TPHs in the sediments and the TOC\% with a correlation factor $(r=0.98)$.

The identification of oil pollution by means of their trace metals content in very suitable. Few metals are present in petroleum product at sufficient high concentration. Nickel and Vanadium are the most commonly ones [35]. Sediment of MOD could receive heavy metals of industrial waste from petroleum related compounds used as fuel. 
Sediments were likely to act as a sink for hydrocarbons. TOC\% and sediments type played a role in the distribution of hydrocarbons, and $\mathrm{V}$ and Ni could be used as indicators of oil pollution in the sediment.

\section{Conclusions}

Results that assess water via a chemical analysis give clear information about the possible physico-chemical causes that may influence the quality status of the natural resource.

Analytical results revealed that station 1 had the highest concentration of TPHs and trace metals in both water and sediments. Trace metals have been referred to as common pollutants, which are widely distributed in the environment with sources mainly from the weathering of minerals and soils. The study also shows a relationship between the concentration of $\mathrm{Ni}$ and V with Total Organic Carbon (TOC\%) in the sediment. In general, the highest concentrations of TPHs were recorded during the winter, while the lowest values were recorded in the summer.

This study reveals that the water of Main Outfall Drain is impacted by high concentration of TPHs and trace metals due to high pollutants from natural and anthropogenic sources of local origin.

\section{References}

[1] Thorhang, A. (1992) The Involvement Fortune of Kuwaits. In: Al-Shatti, A.K. and Hurigtion, J.M., Eds., Proceedings of International Symposium on the Environment and the Health Impacts of the Kuwaiti Oil Fires, The University of Birmingham Press, Edgbaston, 94.

[2] Carbioch, L., Dauvin, J.C. and Gentil, F. (1977) Preliminary Observations on Pollution of the Seabed and Disturbance of Sub-Littoral Communities in Northern Brittany by Oil from at the Amoco Cardiz. Marine Pollution Bulletin, 9, 303-307. http://dx.doi.org/10.1016/0025-326X(78)90255-2

[3] Farrington, J.W., Frew, N.M., Gschwed, P.W. and Tripp, B.W. (1977) Hydrocarbons in North-Western Atlantic Coastal and Continental Margin Sediments. Estuarine Coastal Marian Science, 5, 792-808.

[4] Patin, S. (1999) Environmental Impact of the Offshore Oil and Gas Industry. Eco Monitor Publishing, New York, 425.

[5] Committee on Oil in the Sea (2003) Oil in the Sea III: Inputs, Fates, and Effects. The National Academies Press, Washington DC. www.nap.edu

[6] Al-Saad, H.T., Darmoian, S.A. and Al-Jassim, H.N.A. (2000) State of Oil Pollution in the Sediments of Northern-West Araubian Gulf after the 1991 Gulf Oil Spill. Journal of Marine Mesopotamia, 15, 145-156.

[7] Al-Timari, A.A. (2000) Oil Pollution in Shatt Al-Arab Water: Studying the Monthly Variations of Polycyclic Aromatic Hydrocarbons (PAHs). Journal of Marine Mesopotamia, 15, 535-548.

[8] Al-Imarah, F.J.M., Ali, S.A. and Ali, A.A. (2010) Temporal and Spatial Variations of Petroleum Hydrocarbons in Water and Sediments from Northern Parts of Shatt Al-Arab River, Iraq. Journal of Marine Mesopotamia Sciences, 25, 65-74.

[9] Al-Kubaysi, A.A. (1996) The Ecological Study of Suddam River. Ph.D. Thesis, University of Baghdad, Baghdad, 143.

[10] Mohammed, S.S. (2010) Evaluation the Quality of Water in Al-Masab Alamm River in Thi-Qar Governorate. M.Sc. Thesis, Thi Qar University, Nasiriyah, 106.

[11] Maktoof, A.A. (2013) Food Habits of Barbus luteus in Main Outfall Drain, Iraq. Natural Science, 5, 848-856. http://dx.doi.org/10.4236/ns.2013.57102

[12] Gaudette, H.E., Flight, W.R., Toner, L. and Folger, D.W. (1974) An Inexpensive Titration Method for the Determination of Organic Carbon in Recent Sediments. Journal of Sedimentary Petrology, 44, 249-253.

[13] Parsons, T.R., Maita, Y. and Lalli, C.M. (1984) A Manual of Chemical and Biological Methods for Seawater Analysis Pergamon. Pergamon Press, Oxford, 173 p.

[14] Goutx, M.A. and Saliot, A. (1980) Relationship between Dissolved and Particulate Fatty Acids, Hydrocarbons, Chlorophyll $a$ and Zooplankton Biomass in Ville Franche Bay, Mediterranean Sea. Marian Chemistry, 8, 299-318. http://dx.doi.org/10.1016/0304-4203(80)90019-5

[15] Howell, F.N. (1961-1962) Standard Methods Chemical Analysis. 6th Edition, D. VNA Nostran Company, Inc., Prineeton.

[16] Riely, J.P. and Taylor, D. (1968) Chelating Resins for the Concentration of Trace Elements from Sea Water and Their Analytical Use in Conjunction with Atomic Absorption Spectrophotometer. Analytica Chimica Acta, 40, 479-485.

[17] Strugen, R.E., Desaulnicrs, J.A., Berman, S.S. and Russell, D.S. (1982) Determination of Trace Metals in Estuarine Sediment by Graphite Furnace Atomic Absorption Spectrophotometer. Analytica Chimica Acta, 134, 288-291. 
[18] Chester, R. and Voutsinou, F.G. (1981) The Initial Assessment of Trace Metal Pollution in Coastal Sediments. Marine Pollution Bulletin, 12, 84-91. http://dx.doi.org/10.1016/0025-326X(81)90198-3

[19] Morgan, M.D., Morgan, J.M. and Wiersma, J.H. (1993) Environmental Science. Manging Biological and Kliassan Stream, Sulaimani, Kurdistant Region of Iraq. M.Sc. Thesis, Sulaimani University, Sulaymaniyah.

[20] Simpsion, C.D., Mosi, A.A., Cullen, W.R. and Reimer, K. (1996) Composition and Distribution of Polycyclic Aromatic Hydrocarbons in Surficial Marine Sediment from Kilimat Harbour, Canada. Science of the Total Environment, 181, 265-278. http://dx.doi.org/10.1016/0048-9697(95)05026-4

[21] WHO (World Health Organization) (1998) Selected Non-Heterocyclic Hydrocarbon. International Program on Chemical Safety, World Health Organization, Geneva, 202 p.

[22] Zakaria, M.P., Takada, H., Tutsumi, S., Ohna, K., Yamada, J., Kouno, E. and Kumata, H. (2002) Distribution of Poly cyclic Aromatic Hydrocarbons (PAHs) in Rivers and Estuaries in Malaysia: A Wide Spread Input of Petrogenic PAHs. Environmental Science and Technology, 36, 1907-1918. http://dx.doi.org/10.1021/es011278+

[23] Al-Awady, A.A. (2012) Concentration of Some Trace Metals in Water, Sediment and Two Cyprinidae Species in Main Outfall Drain. AL. Nassiriya-Iraq. Ph.D. Thesis, College Science for Woman, University of Baghdad, Baghdad, 204 p.

[24] Elias, N.H. (1989) The Activity of Oil Degrading Bacterial in Khor Al-Zubair. M.Sc. Thesis, Marian Science Centre University of Basrah, Basrah, 130 p.

[25] Al-Saad, H.T. and Al-Timari, A.A. (1993) Seasonal Variations of Dissolved Normal Alkanes in the Water Marshes of Iraq. Marine Pollution Bulletin, 26, 207-212. http://dx.doi.org/10.1016/0025-326X(93)90623-R

[26] Brookes, K.M. (1997) Literature Review Computer Model and Assessment of the Potential Environmental Risks Associated with Creosote Treated Wood Products Used in Aquatic Environment. Western Wood Preservers Institute, 138 p. http://www.wwpinstitute.org/documents/01creo497.pdf

[27] Vrana, B., Pasch, A. and Popp, P. (2001) Polyarmatic Hydrocarbons Concentrations and Patterns in Sediment and Surface Water of Mansfed Region, Saxony-Anhalt, Germany. Journal of Environmental Monitoring, 3, 602-609. http://dx.doi.org/10.1039/b104707h

[28] Narbone, J.F., Djomo, J.F., Ribera, D., Ferrier, V. and Garragues, P. (1999) Accumulation of Polycyclic Aromatic Hydrocarbons Adsorbed to Sediment by the Mollusk Corbicula fluminea. Ecotoxicology and Environmental Safety, 42, 18. http://dx.doi.org/10.1006/eesa.1998.1701

[29] Chindah, A.C., Braide, A.S. and Sibeudu, O.C. (2004) Distribution of Hydrocarbons and Heavy Metals in Sediment and a Crustacean (Shrimp: Penaeus notialis) from the Bonny New Calabar River Estuary, Niger Delta. AJEAMRAGEE, 9, 1-17. http://www.srcosmos.gr/srcosmos/showpub.aspx?aa=8856

[30] Corredor, J.E., Morell, J.M. and Del Castillo, C.E. (1990) Persistence of Spills Crude Oil in the Tropical Intertidal Environment. Marine Pollution Bulletin, 21, 385-392. http://dx.doi.org/10.1016/0025-326X(90)90647-Q

[31] Hughes, P., Mckenzie, P. and Gibbs, C.F. (1975) The Microbial Degradation of Oil in the Sea. Proceedings of the Royal Society B: Biological Sciences, 189, 375-390. http://dx.doi.org/10.1098/rspb.1975.0063

[32] ZoBell, C.E. and Prokop, J.F. (1966) Microbial Oxidation of Mineral Oils in Barataria Bay Bottom Deposits. Zeitschrift für allgemeine Mikrobiologie, 6, 143-162.

[33] Atlas, R.M. (1981) Microbial Degradation of Petroleum Hydrocarbons: An Environmental Perspective. Journal of Microbiological Reviews, 45, 180-209.

[34] Suwanagosoom, S. (2001) Accumulation of Total Petroleum Hydrocarbons in Marine Food Chain around PHE Bay. Rayong Province. M.Sc. Thesis, Faculty of Graduate Studies Mahidol University, Bangkok.

[35] Al-Shahristani, H. and Al-Al-Attyia, M.G. (1972) Trace Elements in Iraqi Oils and Their Relationship to the Origin and Migration of These Oils. In: Vakovic, V., Ed., Trace Elements in Petroleum, Petroleum Publishing Company, Okalahoma, 269. 
Scientific Research Publishing (SCIRP) is one of the largest Open Access journal publishers. It is currently publishing more than 200 open access, online, peer-reviewed journals covering a wide range of academic disciplines. SCIRP serves the worldwide academic communities and contributes to the progress and application of science with its publication.

Other selected journals from SCIRP are listed as below. Submit your manuscript to us via either submit@scirp.org or Online Submission Portal.
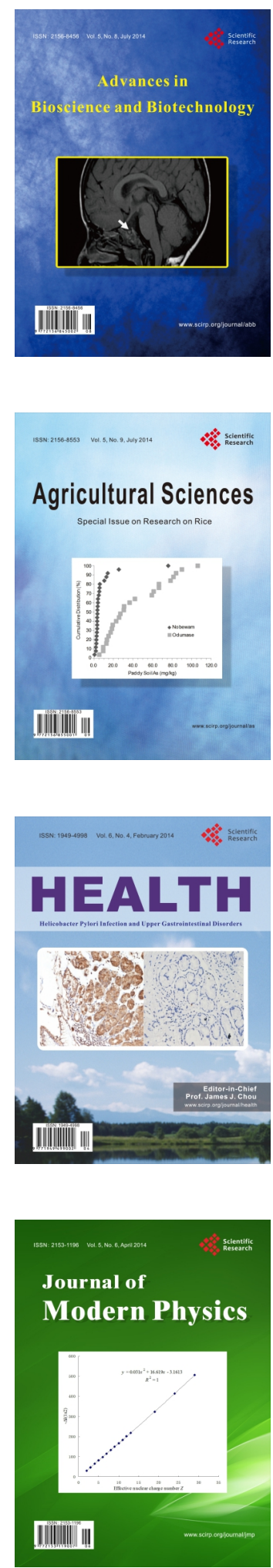
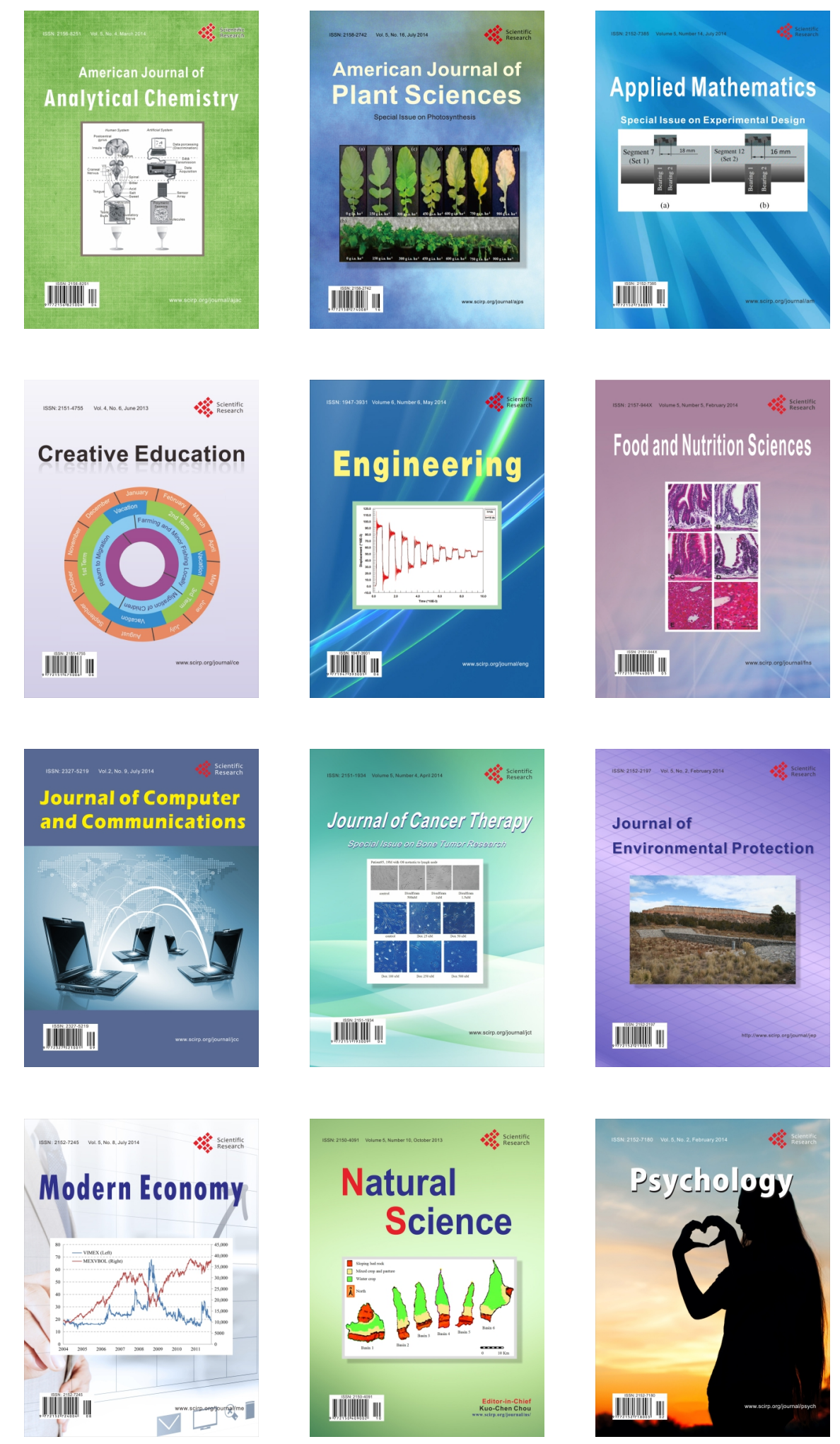